\title{
УДК 631.365:167.23
}

\section{Експериментальні випробування лабораторного стенда для дослідження процесів сушіння}

\author{
Д. В. Гузик ${ }^{1}$ М. П. Єршов² \\ ${ }^{1}$ к.т.н., доцент, Полтавський національний технічний університет імені Юрія Кондратюка, Полтава, Україна, \\ guzikd64@ukr.net \\ ${ }^{2}$ студ. Полтавський національний технічний університет імені Юрія Кондратюка, Полтава, Україна, \\ nikitoshka211072@gmail.com
}

\begin{abstract}
Анотація. У даній статі розглянуто розробку лабораторного стенду для дослідження процесів сушіння. Було проведено різноманітні випробування даного «індивідуального» стенду на аеродинамічні та температурні показники. Великою перевагою даного лабораторного стенду є можливість регулювати кількість повітря, яке проходить через даний стенд та кількість теплоти. Недоліком даного стенду є калориферна установка, яка має занадто велику потужність. У ході випробувань проведено модернізацію установки для покращення вихідних параметрів задля поліпшення перебігу процесу конвективного сушіння. Проведено дослідження конвективного сушіння сливи та інших фруктів. Виконано порівняння конвективного сушіння сливи порівняно з природним сушінням. У подальшому на даному лабораторному стенді можна провести лабораторні дослідження щооо впливу різної кількості (витрати) сушильного агенту при сталій температурі на швидкість сушіння продукції та смакові показники. Також треба зазначити, що даний стенд для дослідження конвективного сушіння можна використовувати для проведення досліджень процесів сушіння овочів, фруктів, ягід, грибів та іншої рослинної сировини як в навчальному прочесі, так і для проведення науково-дослідних робіт.
\end{abstract}

Ключевые слова: сировина, сушильна камера, природне сушіння, конвективне сушіння.

Вступ. Україна - плодоносний край, де вирощують велику кількість різних овочів, фруктів та інших культур. Для збільшення терміну придатності продукти обробляють різними способами, одним з яких є сушіння.

Актуальність дослідження. У наш час застосовують сушіння лікарських трав, ягід, овочів та фруктів. Це дає змогу: зберегти корисні властивості продукції; збільшити термін придатності; зменшити площі та об'єми приміщень для зберігання продукції; зменшити вагу та обсяг продукції під час транспортування, наприклад, у туристичних походах, під час військових дій тощо. Розробка нових технологій для збереження фруктів, ягід, овочів та лікарських трав необхідна для зменшення витрат та отримання продуктів кращої якості й поживної цінності.

Останні дослідження та публікації. Головні вимоги до сушильних установок: забезпечення рівномірного сушіння та отримання високоякісної продукції в усьому об'ємі сушильної камери при високих техніко-економічних показниках: мінімальних габаритах та мінімальних витратах матеріалів на побудову сушарки, мінімальних витратах теплоти та електроенергії на висушування одного кілограма сировини, простому обслуговуванні, зменшення вартості ремонту обладнання. Piвномірність сушіння є одним 3 основних факторів, що характеризують сушильну установку, особливо для установок, призначених для сушіння матеріалів, у яких початкова вологість може змінюватись у широких межах (наприклад, у зерна). Важливою вимогою є можливість висушування партій сировини 3 різною вологістю за один прохід.

Для зменшення тривалості сушіння важливо інтенсифікувати процеси зовнішнього тепло- та масообміну, а для багатьох продуктів і матеріалів інтенсифікувати процеси внутрішнього перенесення теплоти й маси. Для підвищення ефективності й продуктивності установок використовують збільшення напруги, об'єму сушильної камери, сушильні агенти 3 високою початковою температурою, комбіновані методи підведення енергії, раціональне приєднання сушильних установок в енергетичну та теплову схеми підприємства тощо.

Ефективність сушильних установок багато в чому залежить від вибраних методів та режимів сушіння, типу установки та ії розрахунку. Проектування та розрахунок сушильних установок мають базуватися на відомих основних принципах технології сушіння: залежно від властивостей об'єктів сушіння вибирається найбільш раціональний метод $\mathrm{i}$ оптимальний режим сушіння, а на цій основі проводять вибір або розробку сушильної установки [1].

У конвективних сушарках (табл. 1), які найбільше поширені в промисловості, сушильним агентом $\epsilon$ нагріте повітря чи суміш його 3 димовими або топковими газами. 
Основні типи конвективних сушильних установок [2]

\begin{tabular}{|c|c|}
\hline Класифікаційна ознака & Типи сушильних установок \\
\hline $\begin{array}{l}\text { Режим роботи } \\
\text { (спосіб дії) }\end{array}$ & $\begin{array}{l}\text { а) періодичної дії; } \\
\text { б) неперервної дії; } \\
\text { в) циклічної дії. }\end{array}$ \\
\hline $\begin{array}{l}\text { Вид матеріалу, } \\
\text { що висушується }\end{array}$ & $\begin{array}{l}\text { а) кусковий (поштучний); } \\
\text { б) зернистий (дисперсний); } \\
\text { в) пилоподібний; } \\
\text { г) пастоподібний; } \\
\text { д) рідкий (розчин). }\end{array}$ \\
\hline $\begin{array}{l}\text { Тиск у сушильній } \\
\text { камері }\end{array}$ & $\begin{array}{l}\text { а) герметичні камери з надлишковим тиском; } \\
\text { б) атмосферні; } \\
\text { в) вакуумні герметичні камери з тиском вище потрійної } \\
\text { точки; } \\
\text { г) середньовакуумні й глибоковакуумні (з тиском нижче } \\
\text { потрійної точки для водяної пари). }\end{array}$ \\
\hline Вид сушильного агента & $\begin{array}{l}\text { а) повітряні; } \\
\text { б) газові; } \\
\text { в) газоповітряні; } \\
\text { г) парові; } \\
\text { д) рідинні. }\end{array}$ \\
\hline $\begin{array}{l}\text { Спосіб створення напору } \\
\text { для переміщення } \\
\text { сушильного агента }\end{array}$ & $\begin{array}{l}\text { а) } 3 \text { природною циркуляцією; } \\
\text { б) } 3 \text { примусовою циркуляцією. }\end{array}$ \\
\hline $\begin{array}{l}\text { Напрямок руху } \\
\text { матеріалу й сушильного } \\
\text { агента }\end{array}$ & $\begin{array}{l}\text { а) прямотокове; } \\
\text { б) протитокове; } \\
\text { в) перехреснотокове. }\end{array}$ \\
\hline $\begin{array}{l}\text { Стан шару матеріалу } \\
\text { (для зернистих } \\
\text { матеріалів) }\end{array}$ & $\begin{array}{l}\text { а) щільний; } \\
\text { б) розрихлений; } \\
\text { в) киплячий; } \\
\text { г) фонтанний; } \\
\text { д) зважений. }\end{array}$ \\
\hline $\begin{array}{l}\text { Спосіб нагрівання } \\
\text { сушильного агента }\end{array}$ & $\begin{array}{l}\text { а) паровими калориферами; } \\
\text { б) водяними калориферами; } \\
\text { в) вогняними калориферами; } \\
\text { г) електрокалориферами. }\end{array}$ \\
\hline $\begin{array}{l}\text { Конструкція сушильної } \\
\text { камери }\end{array}$ & $\begin{array}{l}\text { шафові, камерні, коридорні (тунельні), трубчасті, шнекові, } \\
\text { вальцеві, циліндричні, турбінні, каскадні, карусельні, } \\
\text { конвеєрні (стрічкові, ящикові, люлькові тощо) пневматичні, } \\
\text { розпилювальні та інші }\end{array}$ \\
\hline $\begin{array}{l}\text { Варіант сушильного } \\
\text { процесу }\end{array}$ & $\begin{array}{l}\text { а) викидання сушильного агента назовні; } \\
\text { б) з рециркуляцією сушильного агента; } \\
\text { в) } 3 \text { проміжним підігрівом сушильного агента; } \\
\text { г) } 3 \text { додатковим підігрівом сушильного агента в сушильній } \\
\text { камері. }\end{array}$ \\
\hline $\begin{array}{l}\text { Спосіб видалення пари } \\
\text { та регенерація } \\
\text { відпрацьованого } \\
\text { сушильного агента }\end{array}$ & $\begin{array}{l}\text { а) видалення пари з відпрацьованим сушильним агентом } \\
\text { назовні; } \\
\text { б) змішування зі свіжим агентом і підігрів (рециркуляція); } \\
\text { в) осушення реагентами (силікагелем тощо); } \\
\text { г) конденсація пари в конденсаторі; } \\
\text { д) виморожування парів у конденсаторі за допомогою } \\
\text { холодоагенту. }\end{array}$ \\
\hline
\end{tabular}


Формулювання цілей статті. Метою роботи є розробка лабораторного стенду для дослідження процесів сушіння різноманітної сировини, його перевірка на працездатність та проведення попередніх досліджень процесів сушіння, а також визначення недоліків та переваг різних способів сушіння сировини.

Дослідний стенд. Розробка нових технологій для збереження плодів та ягід необхідна для зниження витрат та отримання продуктів кращої якості й поживної цінності. На сьогодні відомо два основних способи сушіння - природне та штучне - конвективне (сушіння нагрітим повітрям). Останній спосіб $є$ більш поширеним. Природне сушіння - дешеве й традиційне, але його застосування залежить від погодних умов і вимагає великих виробничих площ та часу для отримання готової продукції. Крім того, необхідно захистити плоди та ягоди від комах, дрібних тварин та від контакту 3 джерелами забруднень. При конвективному сушінні можна контролювати ці несприятливі фактори та збільшити середню швидкість сушіння, але експлуатаційні витрати при цьому збільшуються $[2,3]$.

Для дослідження процесів сушіння в лабораторії кафедри теплогазопостачання, вентиляції та теплоенергетики Полтавського національного технічного університету імені
Юрія Кондратюка було розроблено стенд камерної конвективної сушарки (рис. 1).

Основним елементом розробленої конвективної сушарки $\epsilon$ камера, всередині якої розташовують сировину, що залишається нерухомою протягом усього процесу сушіння [4]. Для забезпечення руху повітря, що виступає як агент сушіння, було використано канальний вентилятор фірми Systemair (Швеція) типу KV 160 M 3 частотним регулятором. Це дало змогу регулювати кількість обертів робочого колеса нагнітача та, відповідно, регулювати кількість повітря, що проходило крізь камеру.

Для підігріву повітря було використано електричний калорифер фірми Aerostar (Україна) марки SEH 50-25/22,5. Цей калорифер має дев'ять ТЕНів, кожний потужністю 2,5 кВт. Відповідно його сумарна потужність становить 22,5 кВт. Розроблений стенд має можливість модуляції у використанні одного, двох, трьох чи більшої кількості ТЕНів залежно від витрати агента сушіння та необхідної температури.

Сушильна камера вертикальна. Стінки камери зроблені з дерев'яних щитів, які ззовні утеплені пінопластом завтовшки 25 мм. Внутрішня поверхня щитів вкрита прошарком харчової фольги, для зменшення тепловтрат за рахунок променевої складової.

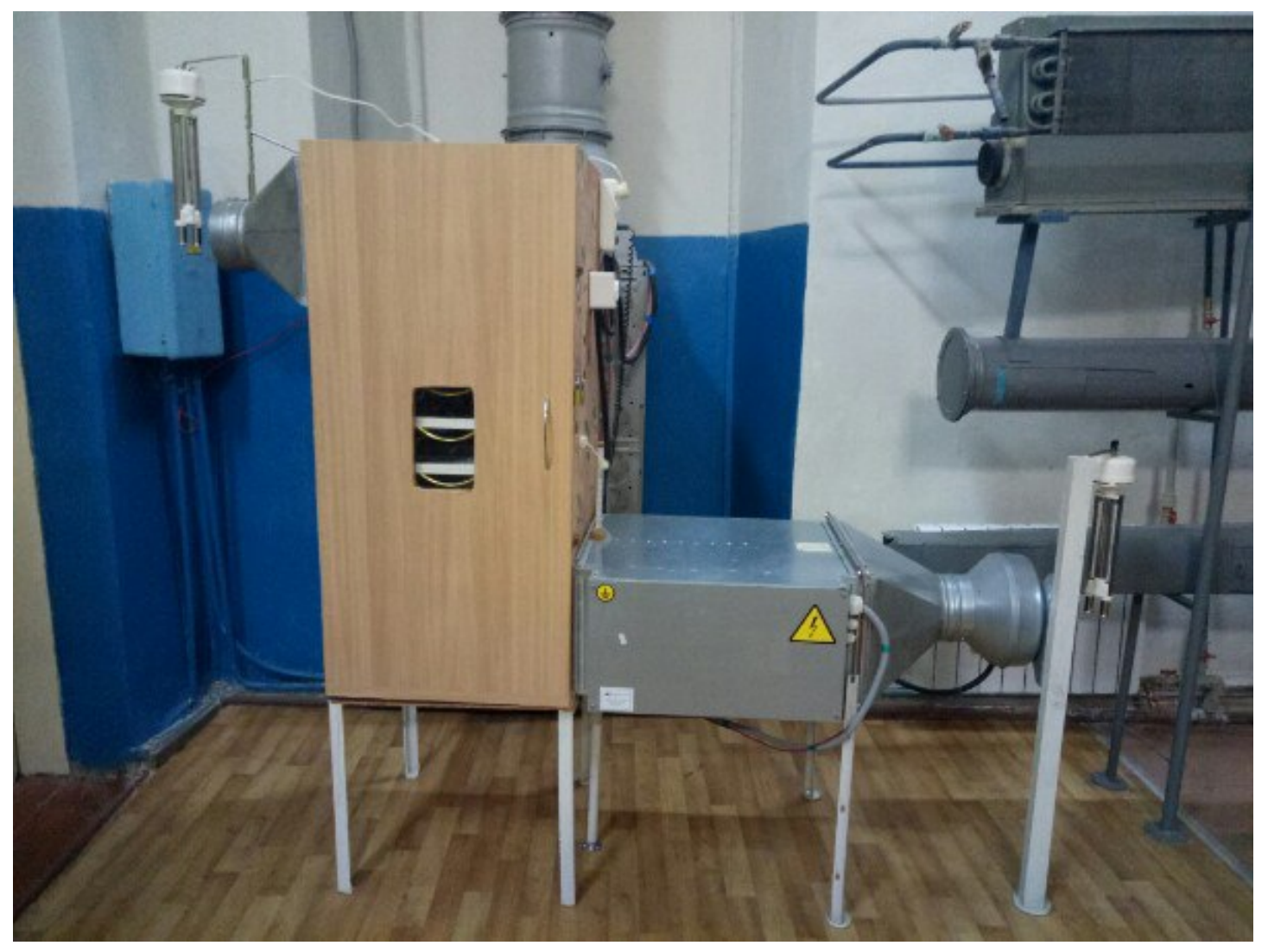

Рис. 1. Загальний вид стенда 
У дверцятах камери було зроблено віконце для можливості візуально спостерігати за процесами, що відбуваються всередині.

Для спрямування та рівномірного розповсюдження повітря, що рухається крізь камеру пінополістиролу, були змонтовані напрямні елементи, які також були вкриті фольгою. Для спостережень за процесом сушіння та зняття показів термометра, що вимірював температуру повітря всередині камери, стенд було обладнано лампою “холодного світла” (рис 2).

Для контролю параметрів повітря, що виступало як агент сушіння, на вході та виході 3 камери стенд було встановлено два аспіраційних психрометри марки $\boldsymbol{M B}-4 \boldsymbol{M}$.

Дослідження аеродинамічних характеристик. Після завершення робіт з монтажу стенда й перших пробних пусків устаткування відбулося тестування аеродинамічних характеристик сушарки. Так, для перевірки розподілу повітряних потоків у сушильній камері, були проведені лабораторні випробування 3 візуалізації руху повітря крізь камеру. Щоб визначити розподіл потоків у різних площинах за висотою камери, до сушильних рамок рівномірно були прикріплені короткі нитки. Після розміщення сушильних рамок по всій висоті сушильної камери й увімкнення нагнітача, через оглядове віконце були проведені візуальні спостереження 3 метою визначення “застійних зон”. Досліди показали наявність таких зон, оскільки на деяких частинах рамок нитки майже не ворушилися. Для запобігання утворення "застійних зон” та задля рівномірного розподілу повітряних потоків у камері було встановлено шибер (рис. 2), що дало змогу вирівняти епюру повітряного потоку за всією висотою камери й одночасно проводити сушіння на всіх ярусах даного стенду.

Дослідження температурного режиму. Після визначення аеродинамічних характеристик лабораторного стенда були проведені дослідження температурного режиму устаткування.

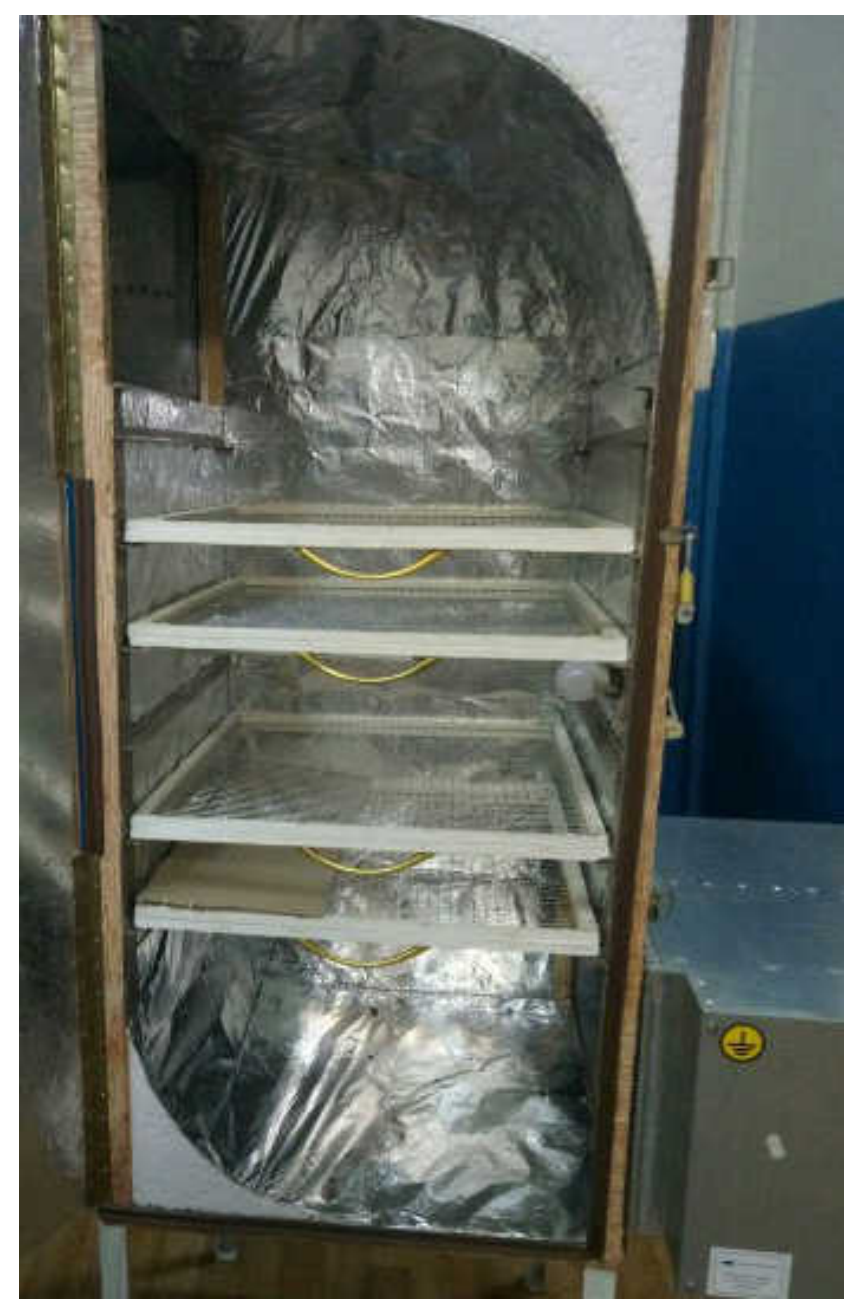

Рис. 2. Внутрішнє облаштування камери 
Метою проведених досліджень було визначення можливості регулювання кількісноякісних показників параметрів агента сушіння, a саме, його температури та витрати. Перший параметр регулювався шляхом увімкнення одного, двох або трьох ТЕНів, відповідно, сумарною тепловою потужністю $2,5,5,0$ та 7,5 кВт. Другий параметр - це кількість (швидкість) повітря - зміна якого здійснювалася за допомогою частотного перетворювача. Сам експеримент проводився в три етапи, при увімкненні одного, двох та трьох ТЕНів відповідно.

На кожному етапі проводилися заміри температури при зміні витрати повітря. За результатами випробовувань було побудовано графік зміни температури у камері залежно від витрати агента сушіння (рис. 3).

На кожному етапі проводилися заміри температури при зміні витрати повітря. За результатами випробовувань було збудовано графік зміни температури у камері в залежності від витрати агента сушіння (рис. 3).

Дослідження процесів сушіння. При плануванні натурного експерименту було виявлено проблему майже повної відсутності літератури, в якій би чітко прописувався регламент ведення процесу сушіння конкретної сировини 3 чітко встановленими як температурними графіками, так і графіками швидкості (витрати) повітря.

Через те, що частково була доступна інформація про сушіння слив, а досліди проводилися саме у вересні-жовтні 2017 року, то саме цей продукт був вибраний нами для дослідження переваг та недоліків процесів природного та штучного конвективного сушіння.

Перед сушінням чисті сливи були розрізані навпіл, 3 них була видалена кісточка. Надалі натурний експеримент проводився 3 двома рівними за вагою партіями слив, одна 3 яких розміщувалась у сушарці (досліджувався процес примусового конвективного сушіння), а друга розташовувалася на такому ж “ситі”, але його було розміщено над корпусом електрокалорифера лабораторного стенда на відстані 100 мм (рис. 4).

Дослід тривав три дні. Кожного дня сушіння проводилося протягом 4-5 годин. Рекомендована температура для сушіння сливи в перший період складає $45 \ldots 500{ }^{\circ} \mathrm{C}$, далі температуру можна збільшити до $700{ }^{\circ} \mathrm{C}$. Графік зміни температурного режиму протягом всього періоду сушіння у камері наведено нижче $[3,4]$ (рис. 5).

Було прийнято рішення оцінювати інтенсивність сушіння плодів сливи через втрату іiі маси, тобто кожне сушіння починалося і закінчувалося замірами маси продукту. Вимір маси продукту на початку та в кінці процесу сушіння здійснювався за допомогою побутових електронних ваг фірми Elenberg з точністю 1 г.

За результатами натурних досліджень залежно від часу та способу сушіння сировини було побудовано графік зміни маси плодів сливи (рис. 6). При цьому закінчення експерименту (через 14 годин після початку) визначалося саме якісними показниками кінцевого продукту - чорносливу, який першим був отриманий саме при використанні штучного конвективного сушіння.

Висновки. Аеродинамічні випробування розробленого стенда дають підстави говорити про доцільність організації руху агента сушіння чітко вздовж вертикалі, тобто для запобігання утворення "застійних зон” підведення та відведення повітря бажано здійснювати відповідно в днище та 3 кришки камери.

Для отримання якісного кінцевого продукту бажано використовувати устаткування для сушіння сировини, яке дає можливість експлуатаційникам одночасно змінювати параметри агента сушіння, а саме як його температуру, так і кількість повітря.

Порівняльний аналіз способів сушіння 3 точки зору строків отримання якісного кінцевого продукту дає перевагу на користь штучного конвективного сушіння. Збільшення експлуатаційних витрат при цьому способі сушіння потребують проведення додаткових лабораторних досліджень.

Попередні випробування створеного лабораторного стенда дають можливість використовувати його для проведення процесів сушіння овочів, фруктів, ягід, грибів та іншої рослинної сировини як у навчальному процесі, так i для проведення науково-дослідних робіт. 

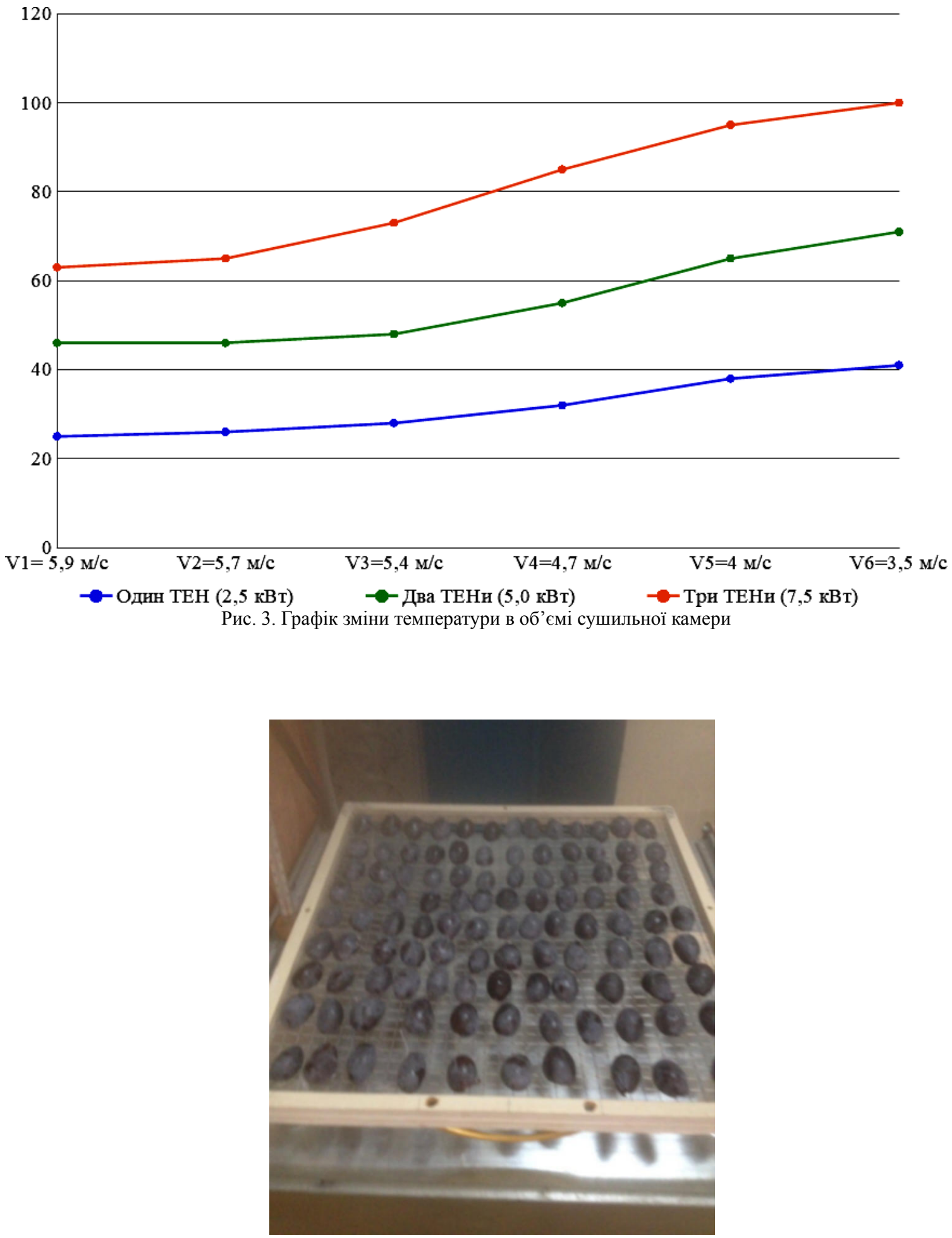

Рис. 4. Організація процесу природного сушіння під час проведення експерименту 


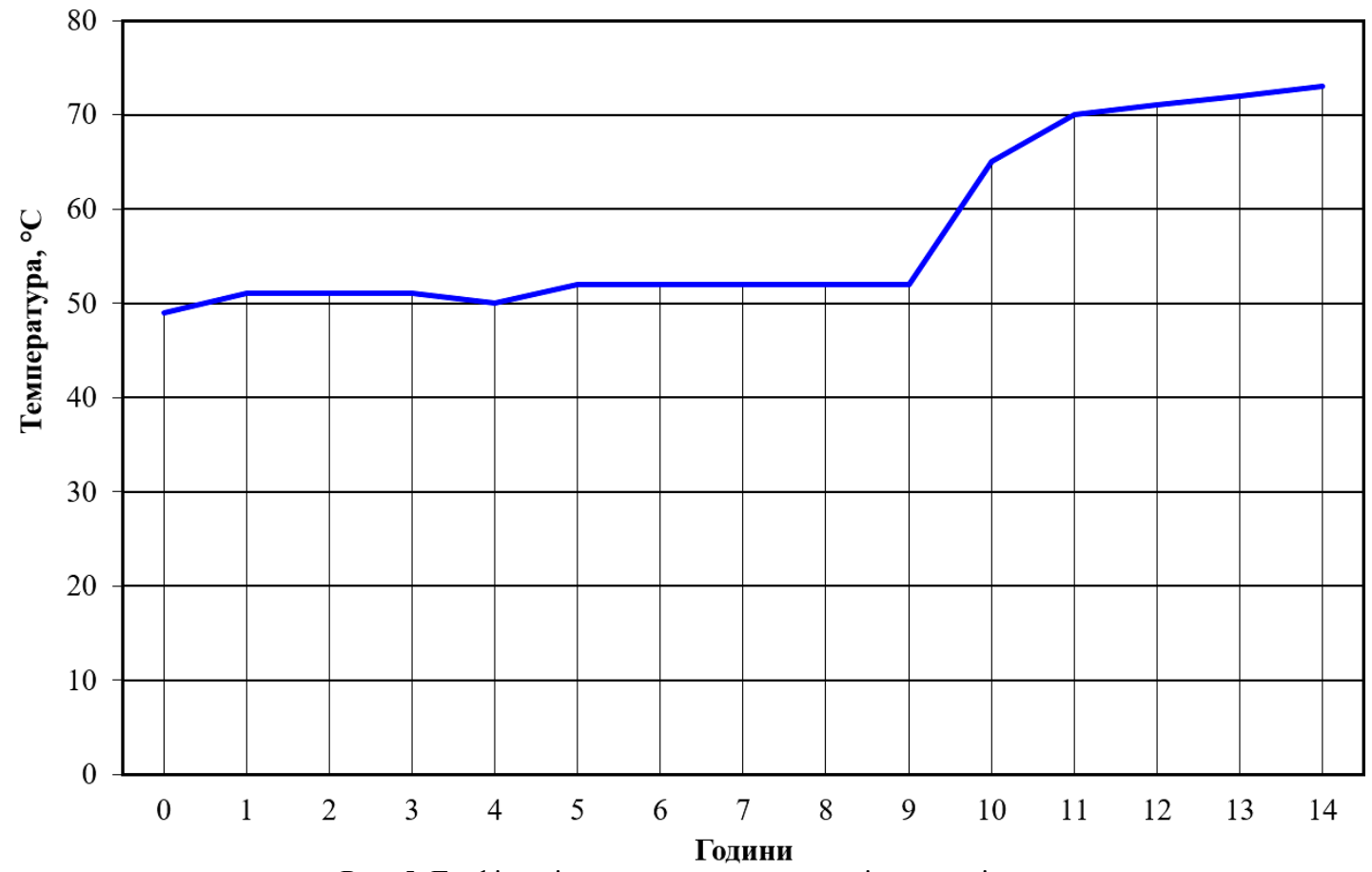

Рис. 5. Графік зміни температури в камері для сушіння

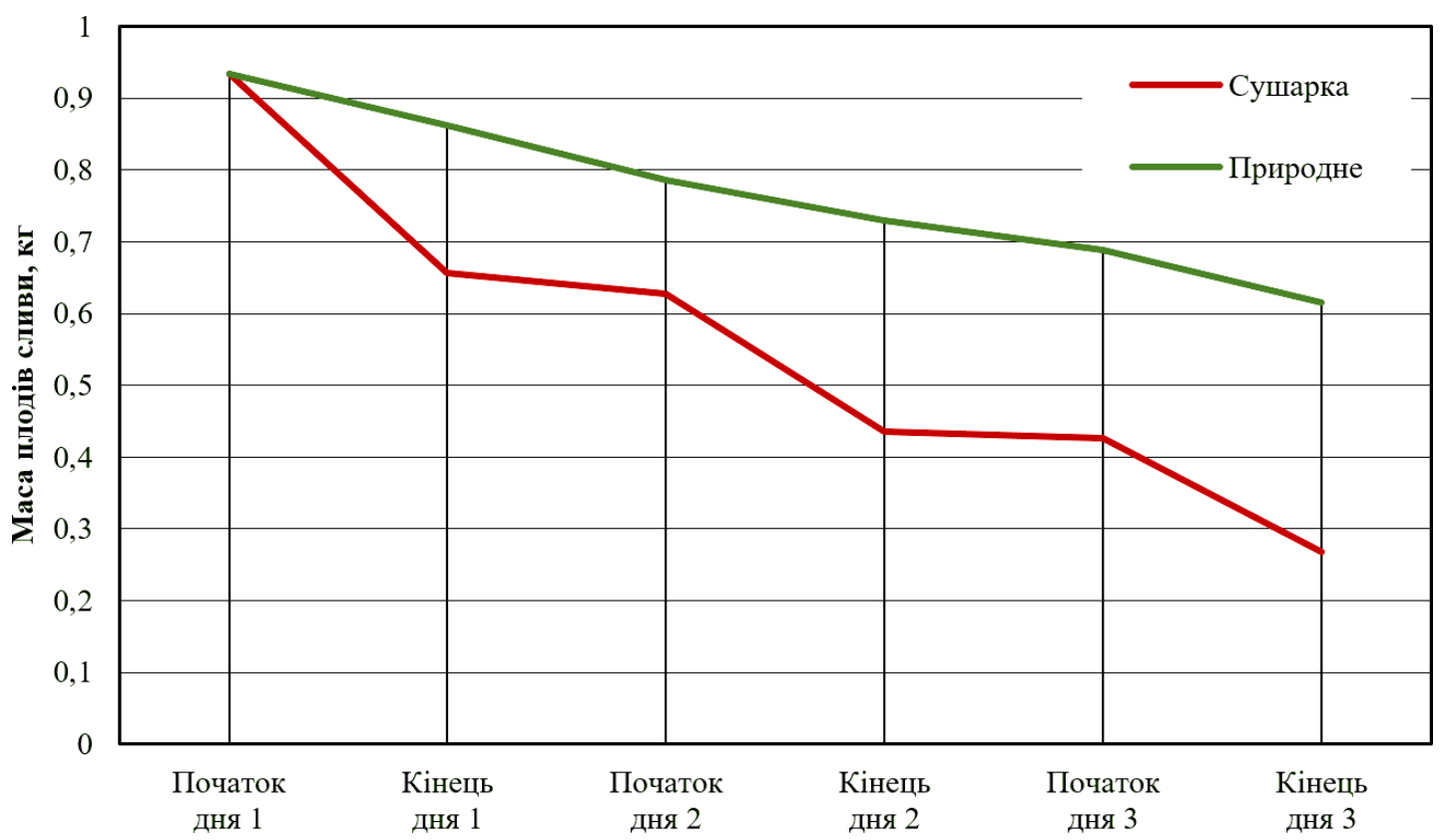

Рис. 6. Втрати маси плодів сливи залежно від способу сушіння 


\title{
Література
}

1. Ткаченко С. Й. Сушильні процеси та установки: навч. пос. / С. Й.Ткаченко, О. Ю.Співак. - Вінниця: ВНТУ, 2009. -86 c.

2. Теоретичне дослідження способів сушіння овочів та фруктів / Тарасенко Т. А., Свлаш В. В., Нєміріч О. В., Вашека О. М., Гавриш А. В., Кравченко О. І. // Науковий вісник ЛНУВМБТ імені С.3. Гжицького. - 2015. Том 17. - № 4 (64). - c. 148-158.

3. Бессараб О. С. Технологія сушіння плодів та овочів: консп. лек. / О. С. Бессараб, В. В. Шутюк - Київ: НУХT, 2002. - 84 c.

4. Рекомендації до сушіння. http://xcook.info/vopros-otvet/kak-sushit-slivy.html

\section{References}

1. Tkachenko S. I., Spivak O. Yu. Сушильні процеси та установки. VNTU, 2009.

2. Тарасенко T. A., Evlash V. V., Nemirich O. V., Vasheka O. M., Havrysh A. V., Kravchenko O. I. "Teoretychne doslidzhennia sposobiv sushinnia ovochiv ta fruktiv." Naukovyi visnyk LNUVMBT imeni S. Z. Gzhitskoho, vol. 17, no. 4 (64), 2015, pp. 148-158.

3. Bessarab O. S., Shutiuk V. V. Tekhnolohiia sushinnia plodiv ta ovochiv. NUKHT, 2002.

4. Rekomendatsii do sushinnia. http://xcook.info/vopros-otvet/kak-sushit-slivy.html

\section{УДК 631.365:167.23}

\section{Экспериментальные испытания лабораторного стенда для исследования процессов сушки}

\author{
Д. В. Гузик ${ }^{1}$ Н. П. Ершов ${ }^{2}$ \\ ${ }^{1}$ К.т.н., доцент, Полтавский национальный технический университет имени Юрия Кондратюка, Полтава, Украина, \\ guzikd64@ukr.net \\ ${ }^{2}$ Студент, 6 курса, Полтавский национальный технический университет имени Юрия Кондратюка, Полтава, Украина, \\ nikitoshka211072@gmail.com
}

\begin{abstract}
Аннотация. В данной статье рассмотрена разработка лабораторного стенда для исследования процессов сушки. Были проведены разнообразные испытания данного «индивидуального» стенда на аэродинамические и температурные показатели. Больиим преимуществом данного лабораторного стенда является возможность регулировать количество воздуха, проходящего через данный стенд, и количество теплоть. Недостатком данного стенда является калориферная установка, она имеет слишком большую мощность. В ходе испьтаний проведена модернизация установки для улучшения выходных параметров с иелью улучшенного протекания конвективной сушки. Проведено исследование по конвективной сушке сливы и других фруктов. Выполнено сравнение конвективной сушки сливы с естественной сушкой. В дальнейшем на данном лабораторном стенде можно провести лабораторные исследования по сравнению влияния разного количества (расхода) сушильного агента при постоянной температуре на скорость сушки продукиии и вкусовые показатели. Также надо отметить, что данный стенд по исследованию конвективной сушки можно использовать для проведения исследований процессов сушки овощей, фруктов, ягод, грибов и другого растительного сырья как в учебном проиессе, так и для проведения научно-исследовательских работ.
\end{abstract}

Ключевые слова: сырьё, сушильная камера, естественная сушка, конвективная сушка. 


\title{
UDC 631.365:167.23
}

\section{Experimental Tests of a Laboratory Stand for Research of Drying Processes}

\author{
D.V.Guzyk ${ }^{1}$, M.P. Yershov² \\ ${ }^{1} \mathrm{PhD}$, docent, Poltava National Technical Yuri Kondratyuk University Poltava, Ukraine, guzikd64@ukr.net \\ ${ }^{2}$ student, Poltava National Technical Yuri Kondratyuk University Poltava,Ukraine, nikitoshka211072@gmail.com
}

\begin{abstract}
Ukraine is a fruitive land, where we grow a large number of different vegetables, fruits and other crops. To increase the shelf life, the products are processed in different ways, one of which is drying. The development of new technologies for the preservation of fruits, berries, vegetables and medicinal herbs is necessary to reduce costs and obtain products of better quality and nutritional value. In this article, the development of a laboratory stand for the study of drying processes is considered. Various tests of this "individual" stand were conducted on aerodynamic and temperature indices. The great advantage of this laboratory stand is the ability to adjust the amount of air passing through this booth and the amount of heat. The disadvantage of this booth is a calorifer installation that has too much power. During the tests, a modernization of the plant was performed to improve the output parameters for improved convection drying. Convection drying of plums and other fruits was carried out, and comparison of convective drying of plums in comparison with natural drying. Taking into account the previous one, it should be noted that now two main methods of drying are known - natural and artificial, convective (drying with heated air), which is more common. Natural drying is cheap and traditional, but its application depends on the weather conditions and requires large production space and time to receive the finished product. In addition, it is necessary to protect the fruits and berries from insects, small animals and from contact with sources of dirt. With convective drying, you can control these adverse factors and increase the average drying speed, but operating costs increase. In the future, at this laboratory stand, laboratory studies can be carried out to compare the effects of different amounts of "flow" of a drying agent at a constant temperature on the speed of drying of products and taste. It should also be noted that this stand on the study of convective drying can be used to study the processes of drying vegetables, fruits, berries, mushrooms and other plant material in the educational process, as well as for research
\end{abstract}

Key words: raw material, drying chamber, natural drying, convective drying.

Надійшла до редакції / Received 12.09.2018. 